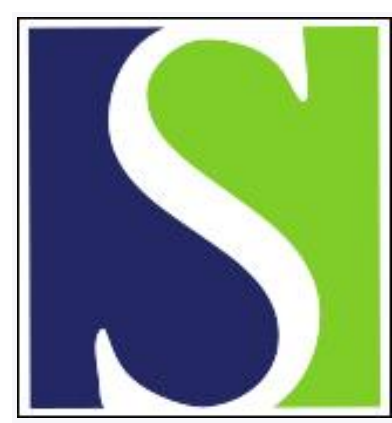

Scand J Work Environ Health 1979;5(1):42-49

https://doi.org/10.5271/sjweh.2667

Issue date: Mar 1979

An exchange of membrane filter samples of airborne asbestos between one United Kingdom and three Scandinavian laboratories.

by Beckett ST, Gylseth B, Krantz S, Paris IM, Schneider T

Key terms: airborne asbestos; asbestos; exchange; fiber; filter; laboratory; membrane; membrane filter sample; microscope;

Scandinavia; United Kingdom

This article in PubMed: www.ncbi.nlm.nih.gov/pubmed/441708

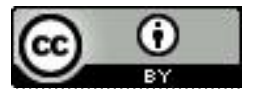


Scand. j. work environ. \& health 5 (1979) $42-49$

\title{
An exchange of membrane filter samples of air- borne asbestos between one United Kingdom and three Scandinavian laboratories
}

\author{
by STEPHEN T. BECKETT, B.Sc., Ph.D, ${ }^{1}$ BJØRN GYLSETH, M.Sc., ${ }^{2}$ STAFFAN \\ KRANTZ, M.Sc., ${ }^{3}$ IRENE M. PARIS, Mi.A., ${ }^{4}$ and THOMAS SCHNEIDER, M.Sc. ${ }^{5}$
}

\begin{abstract}
BECKETT, S. T., GYLSETH, B., KRANTZ, S., PARIS, I. M. and SCHNEIDER, T. An exchange of membrane filter samples of airborne asbestos between one United Kingdom and three Scandinavian laboratories. Scand. j. work environ. \& health 5 (1979) 42-49. An asbestos fiber counting trial based on the postal exchange of mounted and unmounted membrane filter samples was conducted between laboratories in Denmark, Norway, Sweden and the United Kingdom. The exchange was organized on the same basis as a previous international exchange involving nine countries (5); the United Kingdom laboratory had also participated in the previous exchange. Differences in counting techniques were distinguished from those due to the method used to make the filter transparent. Counting techniques gave rise to the biggest differences, giving a ratio of highest to lowest count of 2.75 for amphibole and 3.2 for chrysotile asbestos slides. A comparison was also made with the results of the previous international trial; it was made possible by the recounting of some of the slides from this exchange. Serious deterioration over two years was found in all slides except those mounted with the acetone/triacetin method.
\end{abstract}

Key words: asbestos, fiber, membrane filter, microscope, exchange.

In 1972 a report to the World Health Organization's International Agency for Research on Cancer (IARC) recommended that interlaboratory trials be carried out

1 Institute of Occupational Medicine, Edinburgh, United Kingdom.

2 Yrkeshygienisk institutt, Oslo, Norway.

3 National Board of Occupational Safety and Health, Stockholm, Sweden.

4 Napier College, Edinburgh, United Kingdom.

5 Arbejdsmiljøinstituttet, Hellerup, Denmark.

Reprint requests to: Dr. S. T. Beckett, Institute of Occupational Medicine, 8 Roxburgh Place, Edinburgh EH8 95U, United Kingdom. to standardize the membrane filter method for the evaluation of airborne asbestos (1). As part of this program an exchange of mounted and unmounted membrane filter samples was conducted between laboratories in nine countries (5). Because of the organizational difficulties involved, participation in this trial was limited to one laboratory in each country. Each participant subsequently arranged similar exercises between different centers within their own countries (4). The exercise described in this paper was carried out to extend this work to laboratories in countries which had not previously been involved in international comparison trials. 


\section{ORGANIZATION OF THE TRIAL}

As in the previous trial a single laboratory was chosen to be representative of the country concerned. The Danish, Norwegian and Swedish laboratories were all government establishments, whereas the United Kingdom participant was a research foundation. The exercise was divided into two parts, one on chrysotile and the other on amphibole asbestos, and the procedure was the same in each exchange. Each laboratory prepared and dispatched two cellulose ester membrane filter samples of both types of asbestos to each of the other laboratories. Thus 12 samples were originated by each participant and a total of 48 filters were involved. The laboratories were asked to provide good quality samples of a type frequently found during its routine evaluations. The result reported for each sample was not restricted to that obtained by a single microscopist, but, where desired, a series of individual counts was submitted and the mean value taken to represent the country. So that the effect of the clearing medium upon the final count could be determined and the laboratories could be compared when each was using its own standard method, each filter sample was cut into three sectors (fig. 1). Sector A was mounted and counted (count 1) by the standard method of the originating laboratory. If this method did not result in a sample permanent enough to send to another laboratory, sector B was mounted by an alternative method and counted (count 2). The permanently mounted sector was then dispatched along with the unmounted sector $\mathrm{C}$ to the receiving laboratory. Sector $\mathrm{A}$ or $B$ (as received) was then recounted (count 3 ) and sector $\mathrm{C}$ mounted and counted (count 4) by the standard procedure of the receiving laboratory. Counts 1 and 4 enabled the comparison of the laboratories when using their own standard methods. Differences due to the use of alternative mounting methods were examined by a comparison (where applicable) of counts 1 and 2 and of counts 3 and 4 . Here a single laboratory counted different sectors of the same filter, the only difference being that in certain cases different mounting media had been used.

All comparisons between counts were carried out by an analysis which took into account differences between slides by the method of Beckett and Attfield (2).

The results of the trial showed that the Danish laboratory recorded counts which were much higher than the other three laboratories. In order to determine whether this effect was due to the microscope or the observer, two Danish microscopists recounted several slides both on their own microscope and on that used by the United Kingdom laboratory.

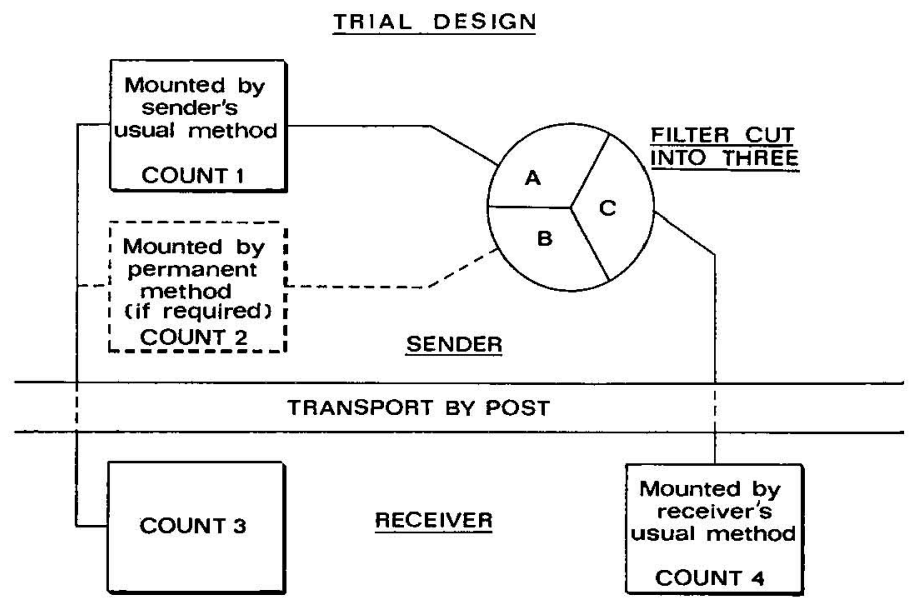

Fig. 1. Trial design. [Reproduced with the permission of the British Occupational Hygiene Society from Ann. occup. hyg. 19 (1976) 217] 


\section{RESULTS}

Details of the microscopes and counting techniques

A summary of the details of the microscopes and counting methods used is given in table 1. All the laboratories used positive phase-contrast microscopes at a magnification of $500-600 \times$. The Norwegian, Danish and United Kingdom laboratories limited the area of the filter being evaluated to that lying within the grid of the eyepiece graticule. The Swedish laboratory, on the other hand,

Table 1. Details of the microscopes and counting methods used in the exchange.

\begin{tabular}{|c|c|c|c|c|}
\hline & Denmark & Norway & Sweden & United Kingdom \\
\hline $\begin{array}{l}\text { Microscope } \\
\text { (make + type) }\end{array}$ & $\begin{array}{l}\text { Zeiss } \\
\text { binocular } \\
\text { +ve phase }\end{array}$ & $\begin{array}{l}\text { Zeiss } 4019922 \\
\text { binocular } \\
\text { + ve phase }\end{array}$ & $\begin{array}{l}\text { Leitz ortholux II } \\
\text { POL Mk } \\
\text { binocular } \\
\text { +ve phase }\end{array}$ & $\begin{array}{l}\text { Vickers M15C } \\
\text { binocular } \\
\text { + ve phase }\end{array}$ \\
\hline $\begin{array}{l}\text { Absorption coefficient } \\
\text { of phase ring }\end{array}$ & Standard & Standard & $75 \%$ & $95 \%$ \\
\hline $\begin{array}{l}\text { Objective } \\
\text { (NA + type) }\end{array}$ & $\begin{array}{l}0.65 \text {, achromat } \\
4546219\end{array}$ & $\begin{array}{l}\text { Ph2 40/0. } 75 W^{a} \\
44627.89160 /-\end{array}$ & 0.65 phaco NPL 40 & 0.7 Ph2 \\
\hline \multicolumn{5}{|l|}{ Magnification } \\
\hline $\begin{array}{l}\text { Objective } \\
\text { Eyepiece } \\
\text { Total }\end{array}$ & $\begin{array}{l}40 \\
12.5 \\
500\end{array}$ & $\begin{array}{l}40 \\
10 \\
500\end{array}$ & $\begin{array}{l}40 \\
12.5 \\
500\end{array}$ & $\begin{array}{l}40 \\
10 \\
600\end{array}$ \\
\hline nlumination & Tungsten Köhlex & $12 \mathrm{v} 60 \mathrm{w}$ Köhler & $\begin{array}{l}\text { Halogenlamp 12v } \\
\text { 50w Köhler }\end{array}$ & $\begin{array}{l}\text { Built-in filament } \\
\text { Köhler }\end{array}$ \\
\hline Filter & Green & Green & Green & Green \\
\hline \multicolumn{5}{|l|}{ Graticule } \\
\hline Type & $\begin{array}{l}\text { Grid } 100 \mu \mathrm{m} \times \\
250 \mu \mathrm{m} \text { divided into } \\
50 \mu \mathrm{m} \text { squares }\end{array}$ & $\begin{array}{l}\text { Grid } 200 \mu \mathrm{m} \times \\
200 \mu \mathrm{m} \text { divided into } \\
10 \mu \mathrm{m} \text { squares }\end{array}$ & Porton & WaIton-Beckett \\
\hline $\begin{array}{l}\text { Object plane }\left(\mathrm{mm}^{2}\right) \\
\text { Full field }\left(\mathrm{mm}^{2}\right)\end{array}$ & $\begin{array}{l}0.025 \\
0.08\end{array}$ & $\begin{array}{l}0.04 \\
0.12\end{array}$ & 0.157 & $\begin{array}{l}0.0079 \\
0.0573\end{array}$ \\
\hline Area evaluated & Graticule & Graticule & Full Field & Graticule \\
\hline $\begin{array}{l}\text { Method used to } \\
\text { choose counting areas }\end{array}$ & $\begin{array}{l}\text { Scanning } \\
\text { intermittently } \\
\text { across the filter }\end{array}$ & $\begin{array}{l}\text { Scanning } \\
\text { intermittently } \\
\text { across the filter }\end{array}$ & $\begin{array}{l}\text { Scanning } \\
\text { intermittently } \\
\text { across the filter }\end{array}$ & $\begin{array}{l}\text { Scanning } \\
\text { intermittently } \\
\text { across the filter }\end{array}$ \\
\hline $\begin{array}{l}\text { Method used to eval- } \\
\text { uate fibers which } \\
\text { were not completely } \\
\text { contained in counting } \\
\text { area }\end{array}$ & $\begin{array}{l}\text { Fiber counted if at } \\
\text { least } 50 \% \text { of its } \\
\text { length is contained } \\
\text { in counting area }\end{array}$ & $\begin{array}{l}\text { Fibers counted } \\
\text { which touch two } \\
\text { selected counting } \\
\text { edges of the square }\end{array}$ & Not counted at all & $\begin{array}{l}\text { Only those fibers } \\
\text { which cross the top } \\
\text { half of the circle and } \\
\text { have an end within it } \\
\text { are counted }\end{array}$ \\
\hline \multicolumn{5}{|l|}{ Fiber definition } \\
\hline $\begin{array}{l}\text { Length } \\
\text { Diameter } \\
\text { Aspect ratio }\end{array}$ & $\begin{array}{l}\geq 5 \\
>3: 1\end{array}$ & $\begin{array}{l}>5 \\
<3 \\
>3: 1\end{array}$ & $\begin{array}{l}>\mathbf{5} \\
<\mathbf{3} \\
>\mathbf{3}: 1\end{array}$ & $\begin{array}{l}>5 \\
<3 \\
>3: 1\end{array}$ \\
\hline $\begin{array}{l}\text { Method used to count } \\
\text { fiber agglomerates }\end{array}$ & $\begin{array}{l}\text { Move on to another } \\
\text { region if agglomer- } \\
\text { ate is not represen- } \\
\text { tative, otherwise } \\
\text { counted as several } \\
\text { fibers }\end{array}$ & $\begin{array}{l}\text { Counted as one } \\
\text { fiber }\end{array}$ & $\begin{array}{l}\text { Agglomerated fibers } \\
\text { are individually } \\
\text { counted if possible; } \\
\text { if it is not possible, } \\
\text { they are not } \\
\text { counted at all }\end{array}$ & $\begin{array}{l}\text { According to Austra- } \\
\text { lian guide to fiber } \\
\text { counting }\end{array}$ \\
\hline Exclusion of fibers & Not in trial & $\begin{array}{l}\text { Only those occur- } \\
\text { ring due to filter } \\
\text { matrix }\end{array}$ & $\begin{array}{l}\text { None which fulfill } \\
\text { size criteria }\end{array}$ & $\begin{array}{l}\text { Any with a morpho- } \\
\text { logy not comparable } \\
\text { with asbestos }\end{array}$ \\
\hline $\begin{array}{l}\text { Number of counters } \\
\text { in exchange }\end{array}$ & 1 & 2 & 3 & 2 \\
\hline
\end{tabular}

a Water immersion objective with long focusing distance. 
evaluated the full field of view of the microscope, at the same time omitting any fibers which were not completely contained in the counting area.

Apart from the Danish laboratory, which did not apply a diameter limit, all the laboratories defined countable fibers as particles with a length to breadth ratio greater than 3 to 1 , length greater than $5 \mu \mathrm{m}$, and diameter less than $3 \mu \mathrm{m}$. As in the previous exchange, varied rules were applied for the counting of clumps of fibers.

\section{Quality of samples}

Each participant assessed the quality of each slide in respect to fiber clarity (in relation to the background and other particulate matter) and fiber density, using fiber categories ranging from "very good" (a) to "very poor" (e). This procedure was carried out both for their own samples and for those received from other laboratories. The average quality assessment was taken to be representative of the slide, and the mean value given for different groups of slides is shown in table 2 . In general most slides were considered to be better than average. The impressions of the slides in the previous international exchange had been much poorer. This difference may have been due the different standards applied by the laboratories involved or to the more widespread use of the Australian mounting method (see next section), which had previously been found to give slides which were considered to be good by most observers.
There was no overall agreement on the optimum density of slide to count, and individual laboratories awarded different assessments to two slides of the same density. The only range of densities to be considered overall as better than average was $100-200$ fibers $/ \mathrm{mm}^{2}$. This value is somewhat sparser than the density preferred in the previous international trial.

\section{Comparison of mounting methods}

Three different techniques were used in the trial to clear the filters. They were acetone vapor and immersion liquid (Ac), dimethyl phthalate with diethyl oxalate and filter (D), and acetone vapor with triacetin on the cover glass ( $\mathrm{Z}$, Australian method).

The methods used by the laboratories to mount the appropriate sectors of the filter are shown in table 3 .

As only the Norwegian and Swedish laboratories mounted sector B, it was only possible to use their results to compare mounting methods when the same sending laboratory made both counts. The ratio of the two methods $\mathrm{D}: \mathrm{Z}$ was 0.94 and 0.92 for amphibole and chrysotile, respectively, with no strong evidence of any real difference between the methods $(\mathrm{P}=$ 0.13 and $P=0.10$, respectively). Table 4 however shows the comparison between mounting methods calculated from counts 3 and 4 made by the same receiving country. The results are presented as ratios to the mean count. This time the differences between the methods were in fact significant $(\mathrm{P}<0.01)$, the ratios

Table 2. Average assessment of background quality and fiber density for different groups of slides.

\begin{tabular}{|c|c|c|c|c|c|c|}
\hline \multirow{3}{*}{ Country } & \multicolumn{3}{|c|}{ Chrysotile } & \multicolumn{3}{|c|}{ Amphibole } \\
\hline & \multicolumn{2}{|c|}{ Slides Dispatched } & \multirow{2}{*}{$\begin{array}{c}\text { Slides } \\
\text { received }\end{array}$} & \multicolumn{2}{|c|}{ Slides Dispatched } & \multirow{2}{*}{$\begin{array}{c}\text { Slides } \\
\text { received }\end{array}$} \\
\hline & $\begin{array}{l}\text { Own } \\
\text { rating }\end{array}$ & $\begin{array}{l}\text { Recipient's } \\
\text { rating }\end{array}$ & & $\begin{array}{l}\text { Own } \\
\text { rating }\end{array}$ & $\begin{array}{l}\text { Recipient's } \\
\text { rating }\end{array}$ & \\
\hline Denmark & Very good & Good & Good & Very good & Good & Very good \\
\hline Norway & Good & Average & Good & Good & Good & Good \\
\hline Sweden & Poor & Average & Good & Very good & Good & Good \\
\hline United Kingdom & Good & Average & Good & Good & Poor & Good \\
\hline
\end{tabular}


Table 3. The mounting methods used by the participating laboratories for the three sectors of the filter.

\begin{tabular}{|c|c|c|c|}
\hline Laboratory & Sector A & Sector B & Sector C \\
\hline Denmark & $\begin{array}{l}\text { Acetone vapor (Ac) } \\
+ \text { immersion liquid } \\
\left(\mathrm{n}_{\mathrm{I}}-1.515\right) \text { between } \\
\text { filter and cover } \\
\text { glass }\end{array}$ & Not mounted & $\begin{array}{l}\text { Acetone vapor } \\
+ \text { immersion liquid }\end{array}$ \\
\hline Norway & $\begin{array}{l}\text { Dimethyl phthalate, } \\
\text { diethyl oxalate }+ \\
\text { filter (D) }\end{array}$ & $\begin{array}{l}\text { Acetone vapor } \\
+ \text { triacetin on cover } \\
\text { glass (Z) }\end{array}$ & $\begin{array}{l}\text { Dimethyl phthalate } \\
\text { diethyl oxalate } \\
+ \text { filter }\end{array}$ \\
\hline Sweden & $\begin{array}{l}\text { Dimethyl phthalate } \\
\text { diethyl oxalate }+ \\
\text { filter }\end{array}$ & $\begin{array}{l}\text { Acetone vapor } \\
+ \text { triacetin on cover } \\
\text { glass }\end{array}$ & $\begin{array}{l}\text { Dimethyl phthalate } \\
\text { diethyl oxalate } \\
+ \text { filter }\end{array}$ \\
\hline United Kingdom & $\begin{array}{l}\text { Acetone vapor } \\
+ \text { triacetin on cover } \\
\text { glass }\end{array}$ & Not mounted & $\begin{array}{l}\text { Acetone vapor } \\
+ \text { triacetin on cover } \\
\text { glass }\end{array}$ \\
\hline
\end{tabular}

$\mathrm{D}: \mathrm{Z}, 0.74$ for amphibole and 0.77 for chrysotile, being much lower than those from counts 1 and 2 . The ratios are however closer to those found in the previous international trial $(0.66$ and 0.84 for amphibole and chrysotile, respectively).

\section{Interlaboratory comparison}

Counts 1 and 4 enable a comparison of laboratories using their own techniques for both mounting and counting the samples. The results are presented in table 5 as ratios to the mean count. Differences between the laboratories were very highly significant $(\mathrm{P}<0.001)$. As can be seen, the counts of the Danish laboratory were two to three times higher than those of the other three laboratories, the counts of which were closer to each other. The Swedish counts were however significantly lower than the United Kingdom ones for amphibole asbestos, while the Norwegian ones were similarly lower for chrysotile ( $\mathrm{P}<0.01$ in both cases).

\section{Comparison with the previous international trial}

As the United Kingdom laboratory took part in both exchanges, it would be possible to compare the two sets of results, provided that any change in the
Table 4. Comparison of mounting methods: Counts 3 and 4.

\begin{tabular}{lcc}
\hline Method & Amphibole & Chrysotile \\
\hline & & \\
Ac & 1.02 & 1.03 \\
D & 0.85 & 0.86 \\
Z & 1.15 & 1.13 \\
\hline
\end{tabular}

Table 5. Comparison between laboratories: Counts 1 and 4.

\begin{tabular}{lcc}
\hline \multirow{2}{*}{ Laboratory } & \multicolumn{2}{c}{ Ratio to the mean count } \\
\cline { 2 - 3 } & Amphibole & Chrysotile \\
\hline & & \\
Denmark & 1.87 & 2.01 \\
Norway & 0.83 & 0.62 \\
Sweden & 0.68 & 0.90 \\
United Kingdom & 0.94 & 0.89 \\
\hline
\end{tabular}

standards of the laboratory could be determined over the two years between the trials. For this purpose, 25 slides which had been stored since the previous exchange were recounted by the United Kingdom laboratory. Any differences between these and the previous counts could be due to a deterioration of the sample or a change in counting level. Deterioration is likely to vary depending upon the type of asbestos and the method 
of mounting the slides; e.g., the presence of acid in the mounting medium could reduce the chrysotile count while leaving the amphibole one unchanged. The samples which had remained transparent had been mounted either by triacetin or by acetone vapor, with triacetin placed between the sample and cover glass (Australian method). The slides were therefore divided into these two groups, which were once again split into amphibole and chrysotile specimens. The mean ratio between the original and repeat counts for each group of slides is given in table 6 . As can be seen, both sets of the triacetin mounted slides gave greatly reduced counts and were found to have a rather poor background. This low count was probably due to migration of the fiber over a wider area and a greater depth of focus that reduced the measured fiber density. This was also indicated by the fact that, where gridded filters were used, the lines had become broken and distorted. The relatively lower count for chrysotile could be due to fibers being dissolved by acetic acid, which is a decomposition product of triacetin. Alternatively this type of asbestos contains a higher proportion of finer fibers, which are the ones most likely to be obscured by a deteriorating background. The amphibole slides mounted by the Australian method, however, gave counts which had not changed significantly over the two years $(\mathrm{P}=0.36)$; this result suggested that the United Kingdom laboratory's counting level had not altered during that period. The chrysotile slides mounted with the Australian method gave a reduced count however. Although this change was much smaller than that which took place in the triacetin mounted slides, some deterioration or change of counting level had taken place.

The ratios of the mean of the counts reported by the participating laboratories in the first exchange to the overall mean level is shown in table 7, the United Kingdom ratio to the mean being 0.85 for amphibole and 1.01 for chrysotile.

The recounts of the samples indicate that the two trials can be directly related for amphibole. Therefore Denmark would have, on the average, reported much higher counts than any other country, while Sweden's results would have been significantly lower than the mean. For chrysotile the relationship is not so definite, but it is unlikely that the counting level of the United Kingdom laboratory has changed by more than $30 \%$. This result suggests that the Danish counting level is again relatively high, and probably very similar to that of the American participant. The Norwegian counts on the other hand are likely to be comparable with the relatively low counts of the Finnish laboratory.

\section{Reevaluation of four slides by the Danish laboratory}

During the trial it was not possible to distinguish differences due to the observer

Table 6. Ratios of recounts after two years to the United Kingdom estimates of the original count.

\begin{tabular}{|c|c|c|c|c|}
\hline $\begin{array}{l}\text { Mounting } \\
\text { method }\end{array}$ & $\begin{array}{l}\text { Asbestos } \\
\text { type }\end{array}$ & $\begin{array}{l}\text { Number } \\
\text { of slides }\end{array}$ & $\begin{array}{l}\text { Ratio of recount } \\
\text { to United Kingdom } \\
\text { estimate of original } \\
\text { count (range) }\end{array}$ & $\begin{array}{c}\text { Significance } \\
\text { P }\end{array}$ \\
\hline \multirow{3}{*}{$\begin{array}{l}\text { Acetone } \\
\text { and } \\
\text { triacetin }\end{array}$} & & & 1.12 & \\
\hline & Amosite & 7 & $\begin{array}{c}(0.92-1.45) \\
0.71\end{array}$ & 0.36 \\
\hline & Chrysotile & 8 & $(0.46-0.96)$ & $<0.001$ \\
\hline \multirow{2}{*}{ Triacetin } & Amosite & 5 & $\begin{array}{c}0.43 \\
(0.22-0.68) \\
0.20\end{array}$ & $<0.001$ \\
\hline & Chrysotile & 5 & $(0.05-0.47)$ & $<0.001$ \\
\hline
\end{tabular}


Table 7. Ratio of the mean of the counts reported by the participating laboratories in the first international exchange to the overall mean level. [Reproduced with the permission of the British Occupational Hygiene Society from Ann. occup. hyg. 19 (1976) 222]

\begin{tabular}{|c|c|c|c|}
\hline \multicolumn{2}{|c|}{ Amphibole } & \multicolumn{2}{|c|}{ Chrysotile } \\
\hline Country & Ratio & Country & Ratio \\
\hline Australia & 1.09 & Australia & 1.02 \\
\hline \multirow[t]{2}{*}{ Belgium } & 1.24 & Belgium & 1.13 \\
\hline & & Canada & 0.94 \\
\hline Finland & 0.74 & Finland & 0.64 \\
\hline France & 0.87 & France & 0.97 \\
\hline Germany & 1.16 & Germany & 0.89 \\
\hline Great Britain & 0.85 & Great Britain & 1.01 \\
\hline \multirow[t]{2}{*}{ South Africa } & 1.18 & South Africa & 0.92 \\
\hline & & United States & 1.81 \\
\hline
\end{tabular}

Table 8. Recounts of four slides on the Danish and United Kingdom microscopes (fibers $/ \mathrm{mm}^{2}$ ).

\begin{tabular}{lccccr}
\hline Slide & $\begin{array}{c}\text { Observer 1, } \\
\text { original trial }\end{array}$ & $\begin{array}{c}\text { United King- } \\
\text { dom trial count a }\end{array}$ & $\begin{array}{c}\text { Observer 2, } \\
\text { United King- } \\
\text { dom microscope }\end{array}$ & $\begin{array}{c}\text { Observer 2, } \\
\text { Danish micro- } \\
\text { scope }\end{array}$ & $\begin{array}{c}\text { Observer 1, re- } \\
\text { count on Dan- } \\
\text { ish microscope a }\end{array}$ \\
Amosite 1 & 89 & 44 & 43 & 34 & 102 \\
Amosite 2 & 151 & 69 & 79 & 64 & 137 \\
Chrysotile 1 & 95 & 43 & 37 & 33 & 56 \\
Chrysotile 2 & 164 & 59 & 94 & 66 & 135 \\
\hline
\end{tabular}

a Mean of two counts.

from those caused by the use of different models of microscopes. So that it could be determined which of the two effects had caused the large difference in counting level, a second microscopist from the Danish laboratory recounted the Danish samples which had been sent to the United Kingdom both on the original microscope and on one in the United Kingdom laboratory. During the latter, the counts for several individual fields of view were carried out in conjunction with a British microscopist. Finally the original Danish participant recounted the samples twice using different eyepiece graticules. The results for the different counts are given in table 8. As can be seen, the second Danish observer recorded results which were very similar to those of the United Kingdom laboratory, on both microscopes, the Danish microscope in fact giving a marginally lower count. A comparison of individual fields of view also indicated that there were slight differences between the laboratories in defining which fibers should be counted, but they appeared to have only a minor effect on the final evaluations. The recounts by the original participant, although lower than his original count, were still approximately twice those of the second observer on the same microscope. A comparison of individual fields of view was therefore carried out by the two Danish microscopists. Major differences were found between the counting rules applied, particularly over the evaluation of fibers not considered to be asbestos and over those fibers which had nonrespirable particles attached (i.e., projected diameter $>5 \mu \mathrm{m})$. Good agreement was achieved between the microscopists however when both used the same counting criteria.

\section{DISCUSSION}

The most significant difference shown by this exchange was that between the Danish and other laboratories. The recount- 
ing of some of the slides indicated that the higher counting level recorded by the original Danish participant was probably due to his application of different rules as to which fibers to count rather than a difference in visual acuity between him and the other counters. It would therefore be desirable that criteria be agreed on internationally with regard to the counting of fibers which do not have the morphology of asbestos or which have particles attached.

The reasons for the relatively low counts of the Norwegian and Swedish laboratories for chrysotile and amphibole slides, respectively, could not be fully determined. As the Swedish laboratory had evaluated the full field of view of the microscope and omitted fibers overlapping the edge, whereas the other participants had only counted the central graticule grid area and included a proportion of the overlapping fibers, it would have been expected that this laboratory would have returned lower results (3). Although it actually did report lower results for the amphibole asbestos samples, the chrysotile slide results were in fact very close to the mean. The relatively low count returned by the Norwegian laboratory for chrysotile was partially due to one of the two observers consistently counting $10-30 \%$ lower than the other for this type of asbestos.

The four laboratories which had participated in this trial had had no previous exchanges of samples. It was therefore expected that large differences would occur. The relatively high count of the Danish laboratory emphasizes the need for continuing checks to be carried out, both within and between different organizations, to ensure that the reported results are comparable.

\section{ACKNOWLEDGMENTS}

The authors wish to thank the many people who evaluated slides as part of this exchange. The support of the British Asbestosis Research Council is also acknowledged.

\section{REFERENCES}

1. ADVISORY COMMITTEE ON ASBESTOS CANCERS. Report to the director of the International Agency for Research on Cancer on the biological effects of asbestos. Ann. occup. hyg. 16 (1973) 9-17.

2. BECKETT, S. T. and ATTFIELD, M. D. Inter-laboratory comparisons of the counting of asbestos fibres sampled on membrane filters. Ann. occup. hyg. 17 (1974) 85-96.

3. BECKETT, S. T., HEY, R. K., HIRST, R., HUNT, R. D., JARVIS, J. L. and RICKARDS, A. L. A comparison of airborne asbestos fibre counting with and without an eyepiece graticule. Ann. occup. hyg. 19 (1976) $69-76$

4. GIBBS, G. W., BARON, P., BECKETT, S. T., DILLEN, R., DU TOIT, R. and ROBOCK, K. A summary of asbestos fibre counting experience in seven countries. Ann. occup. hyg. 20 (1977) $321-332$.

5. WALTON, W. H., ATTFIELD, M. D. and BECKETT, S. T. An international comparison of counts of airborne asbestos fibres sampled on membrane filters. Ann. occup. hyg. 19 (1976) 215-224. 